\title{
ANALISIS PENDAPATAN USAHATANI JAMUR MERANG DAN KONTRIBUSINYA TERHADAP PENDAPATAN RUMAH TANGGA PETANI DI KELURAHAN SEMPUSARI KECAMATAN KALIWATES KABUPATEN JEMBER
}

\author{
*Farah Rizqi Fauziah, Djoko Soejono
}

Program Studi Agribisnis, Fakultas Pertanian, Universitas Jember

*Corresponding author: Farahrizqifauziah@gmail.com

\begin{abstract}
The mushroom farming in Sempusari Village was a subsidiary farm to increase farm household income and it was a diversion commodity from secondary crops. The diversion decided due to there was an opportunity to use the remaining of the house yard. The straw mushroom farmers in this region are still not join any association or farmer groups, so that the farmers do the cultivation independently without any help. This study aims to determine 1) income of straw mushroom farming, 2) production cost efficiency of straw mushroom farming, 3) the contribution of straw mushroom farming profit to the farm household income of farmer households. The research method used descriptive and analytical methods. The sample used total sampling method. Data collection used observation, interview and documentation techniques. Data analysis used income analysis, $R / C$ ratio analysis and income contribution analysis. The results showed that straw mushroom farming in Sempusari subdistricts was profitable, its cost is efficient and the amount contribution of it is rated medium.
\end{abstract}

Keywords: straw mushroom, R/C Ratio, income, efficient, contribution

\begin{abstract}
Abstrak: Usahatani jamur merang di Kelurahan Sempusari merupakan usahatani sampingan untuk menambah pendapatan dan merupakan komoditas pengalihan dari jenis komoditas palawija. Pengalihan dilakukan karena adanya peluang pemanfaatan sisa lahan pekarangan rumah. Petani usahatani jamur merang di wilayah ini belum dinaungi oleh asosiasi atau kelompok tani, sehingga masih di budidayakan secara mandiri tanpa bantuan. Penelitian ini bertujuan untuk mengetahui 1) pendapatan usahatani jamur merang, 2) efisiensi biaya produksi usahatani jamur merang dan 3) kontribusi pendapatan usahatani terhadap pendapatan rumah tangga petani di Kelurahan Sempusari. Metode penelitian menggunakan meode deskriptif dan analitik. Teknik pengambilan sampel yang digunakan adalah Metode Total Sampling. Pengumpulan data menggunakan teknik observasi, wawancara dan dokumentasi. Analisis data menggunakan analisis pendpatan,analisis $\mathrm{R} / \mathrm{C}$ rasio dan Analisis kontribusi pendapatan. Hasil penelitian menunjukkan bahwa pendapatan usahatani jamur merang di Kelurahan Sempusari menguntungkan, biaya produksi usahatani jamur merang sudah efisien dan kontribusi usahatani jamur merang termasuk dalam kategori sedang.
\end{abstract}

Kata Kunci: jamur merang, rasio R/C, pendapatan, efisiensi, kontribusi.

\section{PENDAHULUAN}

Jamur merupakan salah satu komoditas hortikultura sayuran yang mulai banyak diminati oleh masyarakat di Indonesia.
Terdapat 3 jenis jamur yang dibudidayakan dan bisa tumbuh hampir di sebagian besar wilayah di Indonesia. Ketiga jenis jamur tersebut adalah jamur merang, jamur tiram dan jamur kuping. Ketiga jenis jamur ini dapat tumbuh dengan 
baik di Indonesia dikarenakan jenis jamur ini dapat tumbuh pada suhu hangat yang sesuai dengan suhu di Indonesia. Jamur yang tumbuh ini umumnya disebut dengan jamur konsumsi, dimana jenis jamur tersebut merupakan jamur yang dapat dijadikan bahan makanan dan tidak mengandung racun sehingga aman untuk dikonsumsi. Selain itu, tiga jenis jamur ini merupakan jenis jamur yang memiliki prospek untuk di budidayakan di Indonesia (Wiardani, 2010).

Jamur merang merupakan salah satu jenis jamur yang menduduki posisi ketiga dari jenis jamur yang paling penting di dunia. Hal ini didasarkan karena jamur merang memiliki beberapa ciri khas, yaitu jamur merang memiliki cita rasa yang khas. Selain itu jamur merang memiliki siklus yang cepat dalam penanaman sehingga dengan menanam jamur merang memiliki keuntungan untuk cepat dapat merasakan hasil dari panen tersebut. Selain rasa yang khas kelebihan dari komoditas jamur merang ini adalah pada kandungan nutrisinya. (Thiribhuvanamala et al .,2012)

Salah satu wilayah di Kabupaten Jember yang masyarakatnya banyak membudidayakan jamur merang adalah Kelurahan Sempusari, Kecamatan Kaliwates. Usahatani jamur yang ada di Kelurahan Sempusari secara keseluruhan hanya mengusahakan jenis jamur merang, yang dimulai dari adanya potensi jual jamur merang yang cukup baik dan menjanjikan. Hal ini sebagai pendorong bagi masyarakat di Kelurahan Sempusari untuk melakukan usahatani jamur merang. Budidaya jamur merang dilakukan oleh masyarakat di lahan belakang rumah ataupun di daerah pinggiran sungai lingkungan sekitar dengan membangun kumbung sebagai tempat media tanam jamur merang. Berdasarkan hal tersebut menunjukkan bahwa budidaya jamur merang menggunakan pemanfaatan lahan sisa yang biasanya tidak digunakan dan dapat memberikan pendapatan bagi masyarakat yang memanfaatkannya.

Masyarakat di Kelurahan Sempusari melakukan budidaya jamur merang sebagai tambahan pendapatan, dimana sebagian besar masyarakat tersebut memiliki latar belakang pekerjaan sebagai petani, pedagang, buruh tani, dan lain-lain. Umumnya petani yang ada di wilayah tersebut mengusahakan jenis tanaman lain yaitu tanaman palawija. Pemanfaatan lahan sisa yang dimiliki di rumah masing-masing serta peluang harga jual yang cukup baik menjadikan pendorong bagi masyarakat untuk mulai melakukan usahatani jamur merang. Budidaya jamur merang yang sudah dilakukan oleh masyarakat dirasa memberikan pendapatan tambahan bagi petani, hal ini yang menyebabkan masyarakat semakin terdorong untuk mengembangkan budidaya jamur merang, bahkan setiap tahun selalu terjadi penambahan jumlah warga yang memulai usahatani jamur merang, karena melihat petani sebelumnya yang sudah mulai membudidayakan jamur merang.

Budidaya jamur merang ini bagi sebagian masyarakat bukan hanya sebagai pekerjaan sampingan namun sudah mampu menjadi sumber penghasilan utama yang memberikan keuntungan bagi petani yang menjalaninya. Usahatani jamur merang yang terletak di wilayah perkotaan ini merupakan usahatani mandiri, dimana belum terdapat kelompok tani atau asosiasi yang menaungi petani jamur merang di Kelurahan Sempusari. Hal ini menyebabkan petani harus mengalokasikan biaya usahatani yang dikeluarkan seminimal mungkin agar usahatani yang dijalankan dapat efisien dan memberikan pendapatan yang maksimal. Hasil atau pendapatan yang di peroleh dari usahatani jamur merang memberikan tambahan pendapatan bagi rumah tangga petani.

Penelitian ini bertujuan untuk mengetahui 1) pendapatan usahatani jamur merang, 2) efisiensi biaya produksi usahatani jamur merang dan 3) kontribusi pendapatan usahatani terhadap pendapatan rumah tangga petani di Kelurahan Sempusari.

\section{METODOLOGI PENELITIAN}

Penentuan lokasi penelitian dilakukan secara sengaja (purposive method). Menurut Sugiyono (2012), metode purposive merupakan teknik penentuan lokasi dengan menggunakan beberapa pertimbangan tertentu. Lokasi yang ditentukan berada di Kelurahan Sempusari Kecamatan Kaliwates Kabupaten Jember. Pertimbangan lokasi penelitian antara lain usahatani jamur merang merupakan usahatani pengalihan dari komoditas palawija, petani jamur merang masih melakukan budidaya secara otodidak tanpa adanya asosiasi atau kelompok tani yang menaungi, serta usahatani 
jamur merang terletak di wilayah perkotaan dan lahan yang digunakan adalah sisa lahan sekitar yang tidak di manfaatkan.

Metode pengambilan sampel yang digunakan dalam penelitian menggunakan metode total sampling. menurut Sugiyono (2009), total sampling yaitu dimana semua anggota populasi yang ada digunakan menjadi sampel dalam penelitian sehingga seluruh populasi yang berjumlah 11 orang petani di gunakan ssebagai sampel. Seluruh petani yang digunakan sebagai sampel adalah petani jamur merang yang telah memiliki kumbung secara pribadi.

Metode analisis yang digunakan untuk menghitung pendapatan yang diperoleh petani jamur merang baik untuk perhitungan usaha tani jamur merang dan pendapatan lain di luar usahatani jamur merang dilakukan menggunakan analisis pendapatan, menurut Soekartawi (1995), berikut formulasinya :

$$
\begin{aligned}
& \mathrm{Pd}=\mathrm{TR}-\mathrm{TC} \\
& \mathrm{TC}=\mathrm{TFC}+\mathrm{TVC} \\
& \mathrm{YR}=\mathrm{P} . \mathrm{Q}
\end{aligned}
$$

\section{Keterangan :}

$$
\begin{array}{ll}
\mathrm{Pd} & =\text { Pendapatan }(\mathrm{Rp}) \\
\mathrm{TR} & =\text { Total Penerimaan }(\mathrm{Rp}) \\
\mathrm{TC} & =\text { Total Biaya }(\mathrm{Rp}) \\
\mathrm{P} & =\text { Harga Jual }(\mathrm{Rp}) \\
\mathrm{Q} & =\text { Jumlah produksi }(\mathrm{Kg}) \\
\mathrm{TFC} & =\text { Total Biaya Tetap }(\mathrm{Rp}) \\
\mathrm{TVC} & =\text { Total Biaya variabel }(\mathrm{Rp})
\end{array}
$$

Adapun kriteria pengambilan keputusan adalah sebagai berikut :

1. TR > TC, usahatani jamur merang menguntungkan

2. $\mathrm{TR}=\mathrm{TC}$, usahatani jamur merang berada pada titik impas usaha

3. $\mathrm{TR}<\mathrm{TC}$, usahatani jamur merang tidak menguntungkan

Menurut Rahim dan Hastuti (2007), untuk menghitung efisiensi biaya produksi dalam usahatani dapat dilakukan dengan analisis $\mathrm{R} / \mathrm{C}$ ratio. Analisis Return Cost $(R / C)$ ratio merupakan perbandingan (ratio atau nisbah) antara penerimaan (revenue) dengan biaya (cost). Pernyataan tersebut dapat dinyatakan dalam rumus sebagai berikut:

$$
\mathrm{A}=\mathrm{TR} / \mathrm{TC}
$$

Keterangan :

$\mathrm{A}=\mathrm{R} / \mathrm{C}$ Ratio

$\mathrm{TR}=$ Penerimaan petani $(\mathrm{Rp})$

$\mathrm{TC}=$ Biaya produksi $(\mathrm{Rp})$

Adapun kriteria pengambilan keputusan adalah sebagai berikut :

1. TR/TC $>1$, usahatani jamur merang efisien

2. TR/TC $<1$, usahatani jamur merang tidak efisien

3. $\mathrm{TR} / \mathrm{TC}=1$, usahatani jamur merang impas (tidak untung/merugikan)

Metode analisis yang digunakan untuk menjawab rumusan masalah ketiga mengenai besarnya kontribusi pendapatan usahatani jamur merang terhadap pendapatan rumah tangga petani dilakukan dengan menggunakan perhitungan. Menurut Milles dalam Said et al (2015), formulasi presentasi dari perhitungan kontribusi adalah sebagai berikut:

$$
\mathrm{Z}=\mathrm{A} / \mathrm{B} \mathrm{X} 100 \%
$$

Keterangan :

$\mathrm{Z}=$ Kontribusi pendapatan $(\%)$

$\mathrm{A}=$ Pendapatan usahatani jamur merang $(\mathrm{Rp})$

$\mathrm{B}=$ Pendapatan rumah tangga petani (selain dari usahatani dan pendapatan anggota keluarga lain)

Adapun kriteria pengambilan keputusan adalah sebagai berikut:

1. $Z<35 \%$, nilai kontribusi rendah terhadap pendapatan petani

2. $35 \% \leq Z \leq 70 \%$, nilai kontribusi sedang terhadap pendapatan petani

3. $Z>70 \%$, nilai kontribusi tinggi terhadap pendapatan petani.

\section{HASIL DAN PEMBAHASAN}

\section{Pendapatan Usahatani Jamur Merang di Kelurahan Sempusari}

Besarnya pendapatan usahatani jamur merang dapat diketahui dengan analisis pendapatan, yaitu dengan menghitung selisih antara penerimaan yang didapat oleh petani jamur merang dengan total biaya yang dikeluarkan oleh petani jamur merang dalam satu kali 
proses produksi (45 hari).Total penerimaan usahatani jamur merang didapatkan dari jumlah produksi yang dihasilkan dalan satu kali proses produksi dikalikan dengan harga jual jamur merang. Total biaya yang dikeluarkan oleh petani jamur merang merupakan keseluruhan biaya yang dikeluarkan, yang terdiri dari biaya variabel dan biaya tetap.

Total biaya dan total penerimaan yang diperoleh petani akan dapat menunjukkan usahatani jamur merang tersebut memberikan keuntungan atau kerugian. Usahatani jamur merang di Kelurahan Sempusari akan dinyatakan menguntungkan apabila penerimaan yang didapatkan lebih besar daripada biaya yang dikeluarkan. Sebaliknya, usahatani jamur merang dinyatakan rugi apabila penerimaan yang didapatkan lebih kecil daripada biaya yang dikeluarkan. Keseluruhan petani jamur merang di Kelurahan Sempusari memiliki secara pribadi kumbung yang digunakan sebagai tempat budidaya jamur merang.

Tabel 1. Rata-Rata Biaya variabel, biaya tetap dan total biaya usahatani jamur merang di Kelurahan Sempusari Kecamatan Kaliwates dalam satu kali proses produksi per $100 \mathrm{~m}^{2}$

\begin{tabular}{|c|c|c|}
\hline No & Uraian & $\begin{array}{l}\text { Jumlah } \\
\text { (Rp) }\end{array}$ \\
\hline \multirow[t]{10}{*}{1} & Biaya Variabel (VC) & \\
\hline & a. Biaya Bibit & 540.584 \\
\hline & b. Biaya jerami & 2.038 .835 \\
\hline & c. Biaya Bekatul & 9.867 \\
\hline & d. Biaya Kapur & 14.917 \\
\hline & e. Biaya Bahan Pengopenan & \\
\hline & 1. Biaya Kayu & 832.071 \\
\hline & 2. Biaya bensin & 51.013 \\
\hline & f. Biaya Tenaga Kerja & 1.581 .755 \\
\hline & Total Biaya Variabel (TVC) & 5.053 .890 \\
\hline \multirow[t]{5}{*}{2} & Biaya Tetap (FC) & \\
\hline & a. Biaya Pajak Tanah & 1.013 \\
\hline & b. Biaya Sewa Tanah & 225 \\
\hline & $\begin{array}{l}\text { c. Biaya Penyusutan Kum- } \\
\text { bung }\end{array}$ & 1.175 .176 \\
\hline & Total Biaya Tetap (TFC) & 1.176 .416 \\
\hline \multicolumn{2}{|c|}{ Total Biaya (TC) } & 6.230 .304 \\
\hline
\end{tabular}

Sumber : Data Primer diolah tahun 2018

Setiap proses produksi usahatani jamur merang membutuhkan biaya untuk dikeluarkan. Biaya usahatani yang dikeluarkan ini memiliki pengaruh terhadap hasil produksi dari jamur merang, yang akan juga mempengaruhi terhadap hasil pendapatan yang diterima oleh petani jamur merang. Tabel 1 menyajikan ratarata total biaya yang harus dikeluarkan oleh petani jamur merang dalam hitungan luas kumbung per $100 \mathrm{~m}^{2}$.

Berdasarkan perhitungan diketahui bahwa biaya variabel yang terdiri dari biaya bibit, biaya jerami, biaya bekatul, biaya kapur, biaya kayu, biaya bensin dan biaya tenaga kerja manghabiskan total biaya variabel sebesar $\mathrm{Rp}$ 5.053.890. Sedangkan untuk biaya tetap yang terdiri dari biaya pajak tanah, biaya sewa tanah, dan biaya penyusutan kumbung didapatkan total biaya tetap sebesar $\mathrm{Rp}$ 1.176.416. Kemudian untuk mendapatkan total biaya yang dikeluarkan secara keseluruhan adalah dengan menjumlahkan total biaya variabel dengan total biaya tetap sehingga didapatkan jumlah $\mathrm{Rp}$ 6.230.304.

Berdasarkan hasil perhitungan biaya yang dikeluarkan dan penerimaan yang diterima dalam satu kali proses produksi usahatani jamur merang di Kelurahan Sempusari maka dapat dihitung selisihnya untuk mengetahui rata-rata pendapatan atau keuntungan. Tabel 2 menggambarkan perhitungan rata-rata total pendapatan usahatani jamur merang di Kelurahan Sempusari.

Tabel 2. Perhitungan pendapatan usahatani jamur merang di Kelurahan Sempusari Kecamatan Kaliwates dalam satu kali proses produksi per $100 \mathrm{~m}^{2}$

\begin{tabular}{clr}
\hline No & \multicolumn{1}{c}{ Uraian } & \multicolumn{1}{c}{ Jumlah } \\
\hline 1 & Rata-rata produksi $(\mathrm{Kg})$ & 592,9 \\
2 & Rata-rata Harga Jual $(\mathrm{Rp} / \mathrm{Kg})$ & 16.000 \\
3 & Rata-rata total Penerimaan & 9.487 .088 \\
& (Rp) & \\
4 & $\begin{array}{l}\text { Rata-Rata Total biaya produksi } \\
\text { (Rp) }\end{array}$ & 6.230 .306 \\
5 & Rata-rata total pendapatan (Rp) & 3.256 .782 \\
\hline Sumber : Data Primer diolah tahun 2018 &
\end{tabular}

Hasil perhitungan dari analisis menunjukkan bahwa dalam satu kali proses produksi rata-rata produksi jamur merang yang dihasilkan adalah sebesar $592,9 \mathrm{~kg} / 100 \mathrm{~m}^{2}$. Kemudian untuk rata-rata harga jual adalah sebesar Rp 16.000/kg.. Pemanenan jamur merang di Kelurahan Sempusari dilakukan 
selama 20 hari berturut-turut. Jamur merang dipanen setiap hari karena jamur merang memiliki sifat yang cepat mekar setelah dipanen. Berdasarkan hal tersebut, dalam satu hari setelah jamur merang di panen, maka akan langsung dibersihkan dan kemudian langsung dijual kepada pengepul. Jamur merang yang mekar memiliki harga jual yang rendah dan terkadang juga tidak laku dijual kepada pengepul sehingga, terkadang jika petani memiliki jamur yang merang akan di konsumsi sendiri karena tidak dapat dijual ke pengepul ataupun ke pasar.

Penjualan hasil produksi jamur merang di Kelurahan Sempusari secara keseluruhan dijual kepada satu pengepul yang juga merupakan warga Kelurahan Sempusari. Harga yang disepakati oleh seluruh petani dengan pengepul adalah sebesar Rp 16.000/kg. Petani mengirim langsung hasil panen jamur merang ke rumah pengepul yang masih berada dalam satu lingkungan rumah, karena jarak antara rumah seluruh petani dengan pengepul dekat maka jamur merang di antar langsung oleh petani dengan ber jalan kaki sehingga, petani pemilik tidak perlu lagi mengeluarkan biaya.

Pendapatan usahatani jamur merang dengan menghitung selisih antara total penerimaan dengan total biaya, didapatkan jumlah total penerimaan (TR) adalah sebesar Rp 9.487.088 per luasan kumbung $100 \mathrm{~m}^{2}$ dalam satu kali proses produksi (45 hari). Ratarata total biaya didapatkan dari penjumlahan biaya variabel sebesar Rp 5.053.890 dengan rata-rata biaya tetap sejumlah $\mathrm{Rp} 1.176 .416$ sehingga total biaya yang dikeluarkan dalam satu kali proses produksi usahatani jamur merang di Kelurahan Sempusari adalah sebesar Rp 6.230.306 per luasan kumbung $100 \mathrm{~m}^{2}$. Rata-rata pendapatan bersih yang didapatkan dari selisih antara total biaya dengan total penerimaan adalah sebesar Rp 3.256.782 dalam satu kali proses produksi. Nilai tersebut menunjukkan selama 45 hari berlangsungnya proses produksi jamur merang dengan rata-rata luas kumbung keseluruhan petani sebesar $100 \mathrm{~m}^{2}$. Usahatani jamur merang di Kelurahan Sempusari dinyatakan mengalami keuntungan dikarenakan biaya produksi yang dilkeluarkan lebih kecil daripada penerimaan yang didapatkan.

Pendapatan usahatani jamur merang dapat pula dihitung dalam luasan per $1 \mathrm{~m}^{2}$ kumbung. Hal ini bertujuan untuk mengetahui seberapa besar keuntungan yang didapatkan per $1 \mathrm{~m}^{2}$ luasan kumbung sehingga bagi petani yang nantinya ingin menambah luasan kumbung bisa mengetahui dari penambahan tersebut besarnya keuntungan yang akan didapatkan. Selain itu juga dapat memberikan informasi bagi masyarakat yang belum membudidayakan jamur merang agar mempunyai gambaran terhadap keuntungan yang akan didapatkan setiap $1 \mathrm{~m}^{2}$ luasan kumbung jamur merang. Tabel 3 mengilustrasikan perhitungan total pendapatan jamur merang di Keluarahan Sempusari per 1 $\mathrm{m}^{2}$.

Tabel 3. Rata-rata total pendapatan usahatani jamur merang di Kelurahan Sempusari Kecamatan kaliwates dalam satu kali proses produksi per $1 \mathrm{~m}^{2}$

\begin{tabular}{clccc}
\hline No & \multicolumn{3}{c}{ Uraian } & $\begin{array}{c}\text { Jumlah } \\
(\mathrm{Rp})\end{array}$ \\
\hline 1. & $\begin{array}{l}\text { Rata-rata } \\
\left(\mathrm{Rp} / \mathrm{m}^{2}\right)\end{array}$ & total penerimaan & 94.871 \\
2. & $\begin{array}{l}\text { Rata-rata } \\
\left(\mathrm{Rp} / \mathrm{m}^{2}\right)\end{array}$ & total biaya produksi & 62.303 \\
3. & $\begin{array}{l}\text { Rata-rata } \\
\left(\mathrm{Rp} / \mathrm{m}^{2}\right)\end{array}$ & total pendapatan & 32.568 \\
\hline
\end{tabular}

Sumber : Data Primer diolah Tahun 2018

Hasil analisis menunjukkan bahwa ratarata total penerimaan adalah $\mathrm{Rp} 94.871$ per $\mathrm{m}^{2}$ dengan biaya produksi yang dikeluarkan dalam satu kali proses adalah sebesar Rp 62.303 per $\mathrm{m}^{2}$. Berdasarkan nilai pengurangan dari total penerimaan dengan total biaya diketahui bahwa rata-rata total pendapatan yang diterima oleh petani jamur merang per $1 \mathrm{~m}^{2}$ adalah sebesar Rp 32.568. Hal ini menunjukkan bahwa setiap $1 \mathrm{~m}^{2}$ luasan kumbung jamur merang dapat memberikan pendapatan sebesar $\mathrm{Rp} 32.568$ atau dapat dikatakan sudah mampu memberikan keuntungan. Hal ini juga dapat memberikan manfaat bagi masyarakat yang ingin memulai usahatani jamur merang, sehingga dapat memperkirakan seberapa luasan dan jumlah kumbung yang dibutuhkan untuk mendapatkan keuntungan.

Efisiensi Biaya Produksi pada Usahatani Jamur Merang di Kelurahan Sempusari Kecamatan Kaliwates Kabupaten Jember

Pendapatan yang didapatkan oleh petani jamur merang di Kelurahan Sempusari menunjukkan 
hasil yang menguntungkan dengan memperhatikan besarnya biaya yang dikeluarkan dalam satu kali proses produksi usahatani jamur merang. Nilai efisiensi biaya usahatani jamur merang dapat dianalisis menggunakan R/C Ratio yaitu dengan cara melakukan perbandingan antara total penerimaan (TR) dengan biaya yang keluarkan (TC). Setiap petani yang mengeluarkan biaya produksi yang efisien maka akan memberikan pengaruh terhadap pendapatan yang besar dan menguntungkan. Nilai $\mathrm{R} / \mathrm{C}$ ratio nantinya akan menunjukkan efisiensi dari usahatani jamur merang di Kelurahan Sempusari. Efiensi biaya dalam usahatani jamur merang di Kelurahan Sempusari dapat diperoleh dengan menekan biaya produksi dan meningkatkan hasil produksi usahatani jamur merang. Hasil analisis efisiensi biaya produksi pada kegiatan usahatani jamur merang di Kelurahan Sempusari dapat dilihat pada Tabel 4

Tabel 4. Efisiensi penggunaan biaya produksi usahatani jamur merang di Kelurahan Sempusari Kecamatan Kaliwates dalam satu kali proses produksi per $100 \mathrm{~m}^{2}$

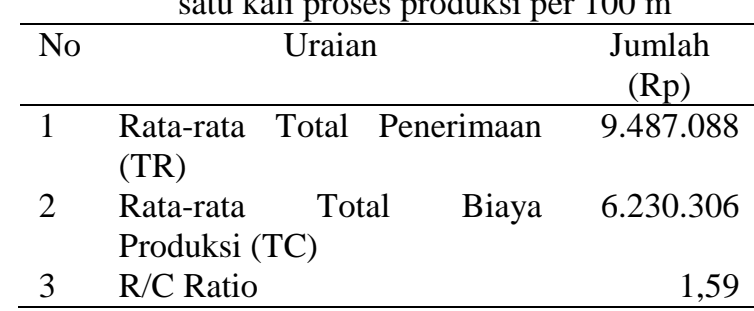

Sumber : Data Primer diolah Tahun 2018

Hasil dari analisis $\mathrm{R} / \mathrm{C}$ ratio akan menunjukkan usahatani jamur merang di Kelurahan Sempusari efisien atau tidak. Apabila nilai R/C Ratio > 1 maka usahatani jamur merang di Kelurahan Sempusari adalah efisien. Kemudian, apabila nilai R/C Ratio $\leq 1$ maka usahatani jamur merang di Kelurahan Sempusari tidak efisien, dan apabila nilai $\mathrm{R} / \mathrm{C}$ ratio $=1$ maka hal ini menunjukkan bahwa usahatanai jamur merang di Kelurahan Sempusari berada di titik impas (tidak untung atau tidak rugi). Berdasarkan hasil analisis diketahui bahwa dari hasil perbandingan antara rata-rata total penerimaan (TR) dalam satu kali proses produksi usahatani jamur merang dengan rata-rata total biaya yang dikeluarkan dalam satu kali proses produksi mendapatkan nilai sebesar 1,59. Artinya, setiap penggunaan Rp1,00 biaya produksi maka akan menghasilkan penerimaan sebesar $\mathrm{Rp}$ 1,59 yang berarti pendapatan yang dihasilkan adalah sebesar $\mathrm{Rp} 0,59$ untuk setiap $\mathrm{Rp} 1,00$ biaya produksi yang digunakan. Hal ini menunjukkan bahwa petani telah menggunakan biaya produksi sebaik mungkin.

\section{Kontribusi Pendapatan Usahatani Jamur Merang terhadap Pendapatan Rumah Tangga Petani di Kelurahan Sempusari Kecamatan Kaliwates Kabupaten Jember}

Usahatani jamur merang di Kelurahan Sempusari merupakan komoditas pengalihan dimana sebelumnya masyarakatnya lebih memilih untuk melakukan usahatani padi. Namun saat ini pendapatan dari usahatani jamur merang merupakan salah satu sumber pendapatan dari kegiatan rumah tangga petani di Kelurahan Sempusari.

Total pendapatan keluarga merupakan penjumlahan secara keseluruhan dari pendapatan petani dalam melakukan usahatani jamur merang dan juga anggota keluarga lainnya yang memiliki pendapatan. Kontribusi usahatani jamur merang dalam satu kali proses produksi yaitu kurang lebih 45 hari dihitung dengan pendapatan dari anggota keluarga lainnya yang sudah disesusaikan dalam hitungan waktu yang sama yaitu kurang lebih 30-45 hari. Tabel 5 menunjukkan data jenis pekerjaan lain dan pekerjaan anggota keluarga lain.

Tabel 5. Data jenis pekerjaan anggota keluarga lain usahatani jamur merang di Kelurahan Sempusari

\begin{tabular}{llcc}
\hline No & Jenis Pekerjaan & $\begin{array}{c}\text { Status di } \\
\text { keluarga }\end{array}$ & Jumlah \\
\hline 1. & Petani Pemilik Padi & Suami & 2 \\
2. & Wiraswasta & Suami & 2 \\
3. & Supir & Suami & 1 \\
4. & Guru Swasta & Istri & 4 \\
5. & Petani Penggarap & Suami & 2 \\
\hline & Total & & 11 \\
\hline
\end{tabular}

Sumber : Data Primer Diolah Tahun 2018

Berdasarkan data diketahui bahwa jenis pekerjaan yang paling banyak di lakukan oleh anggota keluarga lain adalah menjadi guru swasta, yaitu sebanyak 4 orang. Hal ini dikarenakan di daerah Kelurahan Sempusari banyak terdapat sekolah swasta seperti Paud dan TK. Namun, juga ada yang bekerja sebagai petani padi sebanyak 2 orang, wiraswasta 2 orang dan juga untuk petani penggarap atau 
buruh petani juga sebanyak 2 orang. Sedangkan terdapat satu orang yang bekerja sebagai supir dari sebuah perusahaan swasta.

Pendapatan dalam suatu keluarga tidak hanya berasal dari satu sumber yaitu pendapatan kepala keluarga saja, melainkan juga mendapatakan tambahan pendapatan dari anggota keluarga lainnya yang memiliki pendapatan juga. Total pendapatan rumah tangga petani adalah keseluruhan dari pendapatan usahatani jamur merang dan pendapatan lain yang berasal dari dalam keluarga petani yaitu pendapatan yang dihitung tidak hanya berasal dari kepala rumah tangga saja, namun melainkan juga dari jenis pekerjaan lain yang berasal dari pendapatan anggota keluarga lain, yaitu berasal dari suami ataupun istri. Kontribusi pendapatan petani jamur merang terhadap pendapatan rumah tangga petani merupakan sebuah besarnya sumbangan dari hasil pendapatan usahatani jamur merang terhadap total pendapatan rumah tangga petani jamur merang. Perhitungan kontribusi pendapatan usahatani jamur merang dapat diketahui dengan menghitung perbandingan antara pendapatan usahatani jamur merang dengan total pendapatan keluarga.

Petani jamur merang di Kelurahan Sempusari lebih memilih untuk berpindah melakukan usahatani jamur merang karena tersedianya lahan dan bisa mempunyai status kepemilikan sendiri. Selain itu, usahatani jamur merang lebih mudah untuk dilakukan dibandingkan dengan usahatani komoditas lainnya. Saat ini, petani jamur merang di Kelurahan Sempusari dalam kegiatan sehariharinya masih memiliki jenis pekerjaan lainnya seperti pedagang, wiraswasta ataupun guru. Hasil perhitungan kontribusi pendapatan usahatani jamur merang disajikan pada Tabel 6 .

Berdasarkan hasil perhitungan diketahui bahwa dalam satu kali proses produksi usahatani jamur merang yaitu 45 hari diketahui bahwa rata-rata pendapatan usahatani jamur merang adalah sebesar Rp 3.256 .782 per 100 $\mathrm{m}^{2}$ luasan kumbung.

Kemudian untuk rata-rata pendapatan di luar usahatani jamur merang adalah sebesar Rp 4.305.556, sedangkan untuk rata-rata pendapatan anggota keluarga adalah sebesar $\mathrm{Rp}$ 2.158.279. Pendapatan ini berasal dari anggota keluarga yang juga membantu bekerja sebagai
Tabel 6. Kontribusi pendapatan usahatani jamur merang di Kelurahan Sempusari Kecamatan Kaliwates Kabupaten Jember

\begin{tabular}{|c|c|c|}
\hline No & Keterangan & Nilai \\
\hline 1. & Pendapatan & 3.256 .782 \\
\hline & i Jamur Mera & \\
\hline 2. & $\begin{array}{l}\text { ta Pendapatan di luar } \\
\text { hi Jamur Merang (Rp) }\end{array}$ & 4.305 .556 \\
\hline 3. & $\begin{array}{l}\text { Rata-rata Pendapatan anggota } \\
\text { keluarga (Rp) }\end{array}$ & 2.158 .279 \\
\hline 4. & $\begin{array}{l}\text { Rata-rata total pendapatan } \\
\text { (Rp) }\end{array}$ & 9.720 .617 \\
\hline 5. & $\begin{array}{l}\text { Rata-rata } \\
\text { Pendapatan } \\
\text { Merang }(\%)\end{array}$ & 52 \\
\hline
\end{tabular}

Sumber : Data Primer Diolah Tahun 2018

guru, pedagang ataupun wirasawasta. Berdasarkan perhitungan tersebut diketahui untuk rata-rata total pendapatan usahatani jamur merang di Kelurahan Sempusari adalah sebesar Rp 9.720.617 dalam satu kali proses produksi usahatani Jamur Merang yaitu selama 45 hari. Berdasarkan hasil perhitungan kontribusi yaitu dengan cara membandingkan antara rata-rata pendapatan usahatani jamur merang dengan total pendapatan rumah tangga petani didapatkan nilai sebesar 52\%. Hal ini menunjukkan Bahwa nilai dari kontribusi masuk dalam kriteria $35 \% \leq Z \leq 70 \%$, yang artinya bahwa kontribusi usahatani jamur merang masuk dalam kategori sedang.

\section{KESIMPULAN DAN SARAN}

Usahatani jamur merang di Kelurahan Sempusari dalam satu kali proses produksi (45 hari) memiliki rata-rata total pendapatan sebesar $\mathrm{Rp}$ 3.256.782, rata-rata total biaya produksi sebesar 6.230 .306 dan rata-rata total penerimaan sebesar Rp 9.487.088 per luasan kumbung $100 \mathrm{~m}^{2}$. Sehingga total penerimaan (TR) lebih besar daripada total biaya (TC) dan usahatani jamur merang dapat memberikan pendapatan bagi petani.

Usahatani jamur merang di Kelurahan Sempusari dengan membandingkan antara total penerimaan (TR) dan total biaya (TC) didapatkan nilai efisiensi sebesar 1,59 Hal ini menunjukkan bahwa nilai R/C Ratio >1 dan usahatani efisien.

Hasil dari perhitungan kontribusi pendapatan usahatani jamur merang di Kelurahan Sempusari menunjukkan nilai sebesar $52 \%$ se- 
hingga dinyatakan kontribusi pendapatan usahatani termasuk dalam kategori sedang.

\section{DAFTAR PUSTAKA}

Hariyati, Y. 2007. Ekonomi Mikro. Jember : CSS.

Mubyarto. 2003. Pengantar Ekonomi Pertanian. Jakarta: LP3ES.

Padangaran, A. M. 2013. Analisis Kuantitatif Pembiayaan Perusahaan. Bogor: IPB Press.

Rahim, A. dan Hastuti, D.R.D. 2007. Pengantar, teori. Dan kasus Ekonomika Pertanian. Jakarta: Penebar Swadaya.

Sugiyono. 2009. Metode Penelitian Bisnis. Bandung: Alfabeta.

$$
\text { 2012. Metode Penelitian }
$$

Kuantitatif Kualitatif dan $R \& D$. Bandung: Alfabeta.
Said, E.N., Hariyati, Y dan Hartadi, R. 2015. Keuntungan dan Kontribusi Usahatani Kopi Arabika pada Berbagai Pola Tanam Terpadu di Desa Sukorejo Kecamatan Sumber Wringin Kabupaten Bondowoso. Berkala Ilmiah Pertanian, 1(1), 1-6.

Suharjo, E. 2010. Bertanam Jamur Merang di Media Kardus, limbah kapas dan limbah pertanian. Jakarta: Agro Media Pustaka.

Soekartawi. 1995. Analisis Usahatani. Jakarta: UI Press.

Thiribhuvanamala, G., Krishnamoorthy, S., Manoranjitham, K., Praksasm, V. dan Krishnan, S. 2012. Improved Techniques to Enhance the Yield od Paddy straw Mushroom (Volvariella Volvacea) for Commercial Cultivation. African Journal of Biotechnology, 11 (64), 12470-12748. 